\title{
Hemostatic Agent
}

National Cancer Institute

\section{Source}

National Cancer Institute. Hemostatic Agent. NCI Thesaurus. Code C78311.

An agent that promotes hemostasis. 